\title{
Danish rocked my world
}

My life took an unexpected twist when I fell in love with a Dane and moved to Denmark. Faced with mastering the next to impossible Danish language, my modern day fairytale quickly turned into one of the most challenging epochs of my life.

My first encounter with the Danish language was an amusing one. It took place back in 2000 whilst serving as a sailor in the U.S. Navy stationed on the lavish Greek island of Crete. On a warm, summer evening, a few shipmates and I touched down at the local hangout and shortly after found ourselves singing and swaying along with my future Danish girlfriend and a group of her Danish friends. The melody and words were foreign, but we tried our best to imitate the strange sounds being sung so effortlessly by our newfound friends. What we later learned - much to the Dane's amusement - was that they were singing, in Danish, "smuk, som et stjerneskud" (which translated means "beautiful as a shooting star"). In our best effort to emulate these sounds, my friends and I had chosen to sing "smoked salmon, yeah it's good". Close, at least to our untrained ears, but yet so far away! We all had a good laugh, and I thought nothing more of it; learning Danish was not an issue, at least not yet.

\section{You have to speak Danish}

When I decided to leave the military and move to Denmark, I honestly failed to consider a number of factors. I must have been high on love because employment, integration and perhaps most importantly, language, had simply not crossed my mind. Obviously, I knew that Danes spoke Danish, but I assumed that because I spoke English and because I was an American, I could easily integrate and quickly find a job. Besides, during my visits to Denmark, I had experienced that most Danes were highly skilled at speaking English and enjoyed engaging in conversations in English anyway - so why not in the workplace? So, once my "honeymoon" period had run its course, I decided it was time to enter the Danish job market. Geared with five years of military experience (meteorology and oceanography) and college courses, I began applying for a variety of jobs. "Do you speak Danish?" I was asked over and over again. "A little" I would reply - honestly though, I could barely strike up a conversation with the cashier at the 
supermarket. "You have to be able to speak Danish if you want to work in Denmark" was the dejection I had to cope with time and time again. My world began to crumble, and the naive expectation that my American roots and ability to speak English were enough to secure a job in Denmark quickly faded. I had been in Denmark only a few months and Danish had already dealt its first blow.

\section{My wife is a piano}

Defeat was not an option; I was bound and determined to learn Danish if that was what was required to get a job. Unemployed and with an excess of spare time on my hands, I equipped myself with a self-teaching course (audio tapes included) and thus my quest to decipher the Danish language began. It took only a few weeks, however, to realize that that my brilliant plans to teach myself Danish was not progressing fast enough. This became quite clear when I tried to impress my wife one day by saying, "You are my wife" in Danish. I struggled to mumble the basic sentence that I had practiced for days, and they came out sounding remotely correct. So with a boyish smile, I looked to my wife for approval. When she gazed back at me with a sheepish grin, I naturally interpreted this to be a sign of surprise and admiration of my progress. I had done it; I could say a coherent sentence in Danish! She then began to softly chuckle and, much to my dismay, informed me that I had just told her that she was my piano. The following week, I enrolled in Danish courses.

\section{My first real Danish job}

Fortunately, my search for a permanent job took a favourable turn almost after a year. Although an entire year of waiting had failed to live up to my expectations in terms of employment, I had been lucky enough to convince a few employers to hire me and was able to find odd jobs in the mean time. However, this also meant that there was little time to attend Danish courses full-time. This meant, I would mostly speak English during my day jobs and then rush home to spend fours hours learning Danish during evening classes twice a week. All of that hard work finally paid dividends when I landed a full-time job. Still attending night classes, I was far from mastering the Danish language, but I assured my new employer that I was studying Danish, and that I considered this job the perfect opportunity to improve. I had gotten my foot in the door and was determined to make the best of the situation, so I struggled to keep up pace with my Danish colleagues by uttering a few words in Danish here and there just to signal that I was trying. It was a work in progress, and over time my confidence in speaking Danish grew stronger. 
I began speaking less English and before I knew it, I was able to participate in most conversations with my broken Danish. Still though, there was room for improvement.

After almost two years at this position, I began to grow weary. Even though I was able to manage surprisingly well by speaking mediocre Danish, I began to develop a growing intuition that there was little chance of advancing up the career ladder without a formal education to support my ambitious nature. But what should I study, and if I had experienced this much difficulty with basic Danish, how in the world would I fare with academic Danish?

\section{Back to school}

Returning to school had always been a dormant thought. Originally, I had planned on staying in Denmark for a few months and then returning to the U.S. to attend a local college and finish my degree. After three years had elapsed, I knew that there was little chance of this ever happening, so I began weighing my educational opportunities in Denmark. To guide my search, I focused on two things: something business related and if at all possible, preferably taught in English.

My timing could not have been better. The Aarhus School of Business (ASB) had recently put the finishing touches on a new international education that combined my love for marketing and communications and even better, was taught entirely in English. So when I received my acceptance letter in the fall of 2003, I let out a big sigh of relief. I was obviously excited about going back to school and the career opportunities it would present, but most of all I was relieved that I could once again utilize my English skills - at least for the next three years.

\section{My time to shine}

Returning to school after a seven-year interval took some time getting used to, but within a few months, I realized that this was just where I belonged. Over the next three years I was like a sponge and absorbed every piece of information I could get my hands on. It was almost as if someone had drilled a hole in my head and the knowledge was being pumped in. In retrospect, I think that it was more the fact that everything was being taught in English and that I knew this was my chance to prove my worth. It was as if I could finally breathe in knowing that I could engage in intellectual, thought-provoking conversation without having to struggle to find the right words in Danish. It was what I like to describe as my "shining" period because with my newfound confidence, I aimed to shine in everything I did. 
Still though, I knew that I would once again be confronted with Danish when I re-entered the Danish labour market, so I made a pact with my wife that we would continue to speak Danish at home so that I could continue to improve. I also began preparing myself for this transition by participating in a number of school-related activities, which presented the opportunity to gain valuable work experience, but also hone my Danish skills in a business setting. Although I sensed that I was still incapable of communicating as effectively as I would have liked, I persevered and tried to deliver my best. This proved to be a wise decision because others began to take notice that despite my linguistic handicap, I was able to demonstrate remarkable determination. This ultimately led to me being headhunted for my first post-college job just a few days before graduation.

\section{Mission accomplished...almost}

Even though I graduated almost two years ago, I am still at ASB however no longer as a student but as an employee. Today I have the pleasure of helping the school develop its newly formed alumni program, and it is a truly rewarding job that gives me the opportunity to draw upon my experiences and knowledge from the U.S. but also to continue to develop my Danish skills. Even better, I am often able to make use of my mother tongue and have even managed to implement "English Wednesdays" so everyone in my department can enhance their English skills. Still though, most of the internal and external communication is in Danish, but over time I have learned to accept this and adjust accordingly.

I would honestly say that my time in Denmark has provoked an internal struggle that has forced me to realize my strengths and weaknesses when it comes to speaking two languages. The Danish language has certainly rocked my world, and sometimes I can still feel it rocking. Even so, learning Danish has also been a humbling experience to say the very least. I am almost certain that my infatuation with Denmark will not cease any time soon, but on the other hand, I have also gained new perspective and have begun to see bilingualism as a gift and not a burden. Nevertheless, English will always be my preferred language because it is how I can reveal the true me. But communicating in Danish - socially or professionally - has also opened up a whole new world of opportunities that I would have never imagined seven years ago. I have many more friends today and a promising career that would not have been possible if I would have packed my bags and gone back to the U.S. I often think about what advice I would offer myself if I could travel back in time to the moment when I decided to move to Denmark, and the only thing that I can come up with is: 
hold on tight, it is going to be a wild ride!

\section{Author}

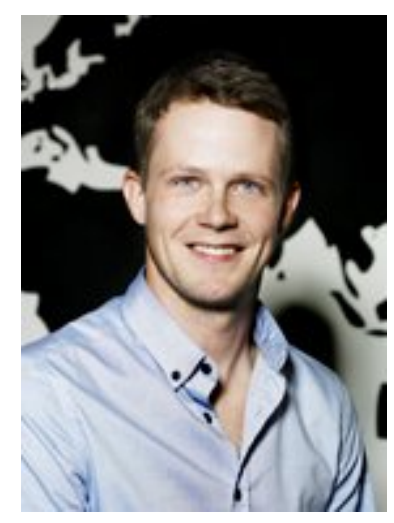

Corey Morris holds a Bachelor of Arts degree in marketing and communications and works as an Alumni Relations Manager at the Aarhus School of Business, University of Aarhus in Denmark.

His job includes establishing, cultivating, and maintaining lifelong relationships between ASB and its former students.

His areas of responsibility cover alumni relations development, international alumni relations and development, marketing and communications plus event management.

For more info, please Visit his staff website.

This article was uploaded to http://www.languageatwork.eu in July of 2009 and published under a "Creative Commons license Attribution Non-commercial (by-nc)" for more information please go to: http://creativecommons.org/about/license/ 